\title{
Dealing with Non-cooperation at the IC C: Towards a More Holistic Approach
}

\author{
Olympia Bekou \\ Professor of Public InternationalLaw; Head, InternationalCriminal \\ Justice Unit, Human Rights Law Centre, School of Law, University of \\ Nottingham, \\ Nottingham, UK \\ olympia.bekou@nottingham.ac.uk
}

\begin{abstract}
The article examines the legal and non-legal responses to tackling non-cooperation with requests issued by the International Criminal Court. Through an examination of the Rome Statute regime as well as the relevant jurisprudence, the paper argues that a shift in the way non-cooperation is dealt with is needed. The article shows both the strengths and limitations of the cooperation system. It concludes that the legal responses of the Court require consistency in order to send a coherent message to non-cooperating States. Ultimately, the article argues that in order to successfully address non-cooperation, it would be important to focus on possible synergies between the legal framework, political tools, actions that are available to States and judicial findings by theCourt.
\end{abstract}

\section{Keywords}

International Criminal Court (ICC) - non-cooperation - judicial findings - Rome Statute - Assembly of States Parties - intergovernmental organisations - Security Council - State parties - non-State Parties

\section{Introduction}

The importance of cooperation with the International Criminal Court (ICC, the Court) and the effects of non-cooperation, are painfully and pragmatically brought to the fore each time an individual indicted for one of the crimes 
falling within the jurisdiction of the Court travels to a State Party and does not get arrested; ' or when the ICC declines the opening of an investigation in the interests of justice, based, among others, on its inability to secure cooperation. ${ }^{2}$ The adoption of the Rome Statute of the International Criminal Court in 1998, marked an important milestone in establishing an international criminal justice system, with the ICC at its centre. A complex international treaty, the Statute strikes a delicate balance between safeguarding State sovereignty and creating a judicial body able to perform its functions.

Part 9, which encompasses the ICC cooperation regime, is an example of the many compromises achieved during the negotiations at Rome. The part on cooperation is the longest part of the Statute, spanning over seventeen provisions. It covers every aspect of cooperation - from arrest, to surrender, to the collection of evidence and the voluntary appearance of witnesses, as well as the postponement of and refusal to execute cooperation requests. ${ }^{4}$

Given that the ICC does not have a police force of its own, relying upon States and intergovernmental organisations (where their competence or man- date allows, and they consent thereto) 6 to provide cooperation is central to

1 Nuba Reports, 'Wanted frequent flyer: Sudan's president has made 74 trips across the world in the seven years he's been wanted for war crimes', QUARTZ Africa, 4 March 2016, qz.com/ africa/630571/suDANS-president-has-made-74-trips-across-the-world-in-the-seven-years- hesbeen-wanted-for-war-crimes/, accessed 29 July 2019. For an interactive map tracking Al Bashir's movements, see the Mapping Bashir Research Project, available at: www .mappingbashir.org/, accessed 31 July 2019.

2 International Criminal Court, Situation in the Islamic Republic of Afghanistan, ICC-02/17-33, Pre-Trial Chamber II, Decision Pursuant to Article 15 of the Rome Statute on the Authorisation of an Investigation into the Situation in the Islamic Republic of Afghanistan, 12 April 2019, paras. 44, 91, 94.

3 Rome Statute of the International Criminal Court (adopted 17 JuLY1998, entered into force 1 July 2002) 2187 UNTS 3 (hereafter 'Rome Statute').

4 Articles 86, 89, 91, 92, 93, 96, 97, 98, Rome Statute.

5 Antonio Cassese, 'On the Current Trends towards Criminal Prosecution and Punishment of Breaches of International Humanitarian', 9(2) European Journal of International Law (1998) 13. In the words of the late Judge Antonio Cassese, who had famously described the ICTY regime in a manner that is also true of the ICC: 'The Tribunal remains very much like a giant without arms and legs - it needs artificial limbs to walk and work. And these artificial limbs are state authorities. If the cooperation of states is not forthcoming, the [Court] cannot fulfil its functions'.

6 Article 87(6), Rome Statute. Forexample, the Negotiated Relationship Agreement between the United Nations and the ICC contains a number of provisions relevant to cooperation. See Article 15-20, International Criminal Court (ICC), Negotiated Relationship Agreement between the International Criminal Court and the United Nations, (ICC-ASP/3/Res.1), 
the Court's success. For the ICC to be able to conduct its investigations and prosecutions, cooperation between the Court, States and international orgaisations is key. As the Rome Statute does not permit trials in absentia, securing the accused's presence and having the evidence required to convict, is dependent upon such cooperation.

The Statute adopts a State-oriented approach, which is unsurprising, given that States are the main actors expected to execute cooperation requests issued by the Court. Although Article 86, which outlines the central cooperation provision, uses mandatory language -'States shall cooperate fully', the provisions that follow take a more pragmatic approach and allow States to navigate the cooperation regime in a manner that is more familiar to them.

The regime crafted in part 9 retains some elements of a horizontal cooperation system, i.e. akin to that employed in inter-State relationships. ${ }^{8}$ For example, the use of a State's own national procedures is permitted, ${ }^{9}$ as opposed to a uniform centralised procedure which would have been too onerous to implement for (potentially) limited cooperation requests. Moreover, rather than re- fusing cooperation outright, States are given the option to request postponing the execution of a cooperation request ${ }^{10}$ which can facilitate cooperation at a later stage, once the obstacles to execution are removed. In that respect, the Statuteprovides a viable framework that aims to anticipatemosteventualities.

When operationalising the cooperation regime, however, the question is not so much what was agreed at Rome, but whether the provisions of the Statute are workable in practice. Unfortunately, with the Court in operation, instances of non-cooperation have become commonplace and as such, have hindered the Court's effective functioning. With the reality of non-cooperation as the starting point for this piece, it is important to consider how the ICC can both operate within the legal framework envisaged in the Statute, whilst also tackling the lack of cooperation and strengthening responses thereto.

The piece therefore provides an in-depth examination of both the legal as well as the non-legal responses to non-cooperation and argues that the Rome Statute regime, on its own, cannot ensure that requests for cooperation are

4 October 2004. An agreement also exists with the European Union. See International Criminal Court (ICC), Agreement between the International Criminal Court and the European Union on cooperation and assistance, (ICC-PRES/01-01-06), 1 May 2006.

7 Article 63, RomeStatute.

8 Goran Sluiter, 'The International Criminal Court and International Criminal Cooperation', in H. von Hebel, J.G. Lammers and J. Schukking (eds.), Reflections on the International Criminal Court (T.M.C Asser Press, The Hague, 1999), 93-96.

9 Articles 93(1), 93(1)(L), 99, Rome Statute.

10 Articles 94 and 95, Rome Statute. 
fulfilled by States. By examining responses to non-cooperation holistically, the piece offers a unique insight that transcends the legal regime established by the Rome Statute and situates the debate in its wider context, which has been overlooked, to date." It is argued that the answer to the non-cooperation conundrum lies in the synergies between better enforcing the Statute's legal regime and providing the necessary political support to tackle and prevent incidents of non-cooperation in the future.

\section{The Rome Statute Provisions on Non-cooperation: Setting Out the Legal Framework}

The text of the Rome Statute sets out the framework in place in order to deal with non-cooperation. Depending on whethernon-cooperation involves State parties, States non-party which are under an obligation to cooperate, intergovernmental organisations, or non-cooperation following a situation referred to the Court by the United Nations Security Council (SC), different provisions apply.

The Rome Statute, being an international treaty, outlines provisions aimed primarily at States that have chosen to become parties to it. The main provision on non-cooperation by a State party, is Article 87(7) of the Rome Statute. This stipulates that where a State party fails to comply with a cooperation re- quest by the Court contrary to the provisions of the Statute, then the Court may make a finding to that effect ${ }^{12}$ and may also inform either the Assembly of States Parties (ASP), or the SC if the situation had originally been referred to the Court by the Council.

11 MicheleCaianiello, 'Models of Judicial Cooperation with AdHoc Tribunals and with the Permanent International Criminal Court in Europe', in S. Ruggeri (ed.), Transnational Inquiries and the Protection of Fundamental Rights in Criminal Proceedings (Springer, Berlin, 2013) 111-23; Thomas Henquet, 'Mandatory Compliance Powers vis-à-vis State by the AdHoc Tribunals and the International Criminal Court: AComparative Analysis', 12 Leiden Journal of International Law (1999) 969; Valerie Oosterveld, Mike Perry and John McManus, 'The Cooperation of Stateswith the International Criminal Court', 25 Fordham International Law Journal (2002) 767; Rod Rastan, 'Testing Co-operation: The International Criminal Court and National Authorities' 21 Leiden Journal of International Law (2008) 431; Patricia M. Wald, 'Apprehending War Criminals: Does International Cooperation Work?', American University International Law Review, (2012) 229.

12 See also International Criminal Court (ICC), Regulations of the Court, (Reg ICC-BD/ 01-03-11), 26 May 2004, Regulation 109(1). 
Oddly, although the main provision on failure to comply with a cooperation request can be found in Article 87(7) Rome Statute, non-cooperation by States that are not party to the Statute and by intergovernmental organisations are dealt with in Article 87(5), which precedes this general provision. Having the specific rule come before the general rule in the Statute, is yet another example of bad drafting, given that the different provisions were belatedly put together as a whole at Rome, precluding the ironing out of such inconsistencies prior to its adoption.

Turning to Article 87(7), the Court is first and foremost, a judicial institution. It is therefore reasonable that the main remedy for noncooperation is a judicial finding to that effect: such a finding is a formal determination by the Chamber that a State has breached its international obligations under the Statute ${ }^{13}$ However, a finding of non-cooperation is at the discretion of the Chamber. Consequently, even if the non-compliance by a State has been determined, such a judicial finding is not automatic and would only be made, if it is deemed appropriate. ${ }^{14}$ Indeed, not all noncooperation proceedings result in a finding of a failure to cooperate. For example, in the case that arose fol- lowing Omar Al Bashir's visit to Nigeria, Pre-Trial Chamber II SIMPLY requested Nigeria to arrest Al Bashir and surrender him to the Court and did not lead to a non-cooperation finding. ${ }^{15}$

When a finding of non-cooperation is made, the matter is then referred to the ASP for consideration. ${ }^{16}$ The involvement of the ASP in this process can be explained because of the governance structure that underpins the Rome Statute regime. As the ASP is the body where all State parties are represented, ${ }^{17}$ it is entirely appropriate to deal with issues of governance, including instances of non-cooperation. ${ }^{18}$ This two-pronged approach that combines a judicial

13 See e.g. ICC, The Prosecutor v. Uhuru Muigai Kenyatta, Case no. ICc-01/09-02/11, Trial Chamber Judgement, Decision on Prosecution's application for a finding on noncompliance under Article 87(7) of the Statute, 3 December 2014.

14 Ibid., ICC, para. 39.

15 ICC, Prosecutor v. Omar Hassan Ahmad Al Bashir, Decision Regarding Omar Al-Bashir's Visit to the Federal Republic of Nigeria, ICC-02/05-01/09, 15 July 2013.

16 Article 112(2)(F), Rome Statute.

17 Daryl A Mundis, 'The Assembly of States Parties and the Institutional Framework of the International Criminal Court',97(1)American Journalof International Law (2003)132-147, DOI: $10.2307 / 3087110$.

18 S. Rama Rao, 'Financing of the Court, Assembly of States Parties and the Preparatory Commission', in R.S. Lee (ed.), The International Criminal Court, The Making of the Rome Statute, Issues, Negotiations, Results (Kluwer, Dordrecht, 1999), pp. 407-413. 
finding by the Court with a response by the ASP aims to tackle non-cooperation by utilising both legal and political tools.

If failure to co-operate relates to a situation originally referred to the ICC by the SC, then the Court's finding may be referred to the SC..$^{19}$ As one of the ICC's trigger mechanisms, SC referrals were included in the Statute as a means of discouraging the creation of new ad hoc Tribunals given the existence of a permanent institution and were also meant to provide the Court with much needed UN funding, to cover the costs of SC referrals. ${ }^{20}$

Following a judicial finding of non-cooperation originating from a $\mathrm{SC}$ referral, it is up to the Council to decide whether or not to take further action. This approach is modelled on the cooperation regime of the Yugoslav and Rwandan ad hoc Tribunals, which had been created following the adoption of SC Resolutions. ${ }^{21}$ With enforcement transferred back to the UN -where the referral originates, the limitations inherent therein, such as the use of the veto power by one of the five permanent members, or the lack of political will to tackle non-compliance, remain. ${ }^{22}$

In all other cases involving State parties, the organ responsible for dealing with non-compliance and deciding on the action to be taken, is the ASP. ${ }^{23}$ The nature of the action is not specified in the Statute. This is surprising given the treaty basis of the Court where rights and obligations are specifically mapped out for each step of the way. This omission may however be explained by the fact that the creation of an ASP was not envisaged in the Draft prepared

19 Article 87(7), Rome Statute. See for instance ICC, The Prosecutorv.Ahmad Muhammad Harun ('Ahmad Harun') and Ali Muhammad Ali Abd-Al-Rahman ('AliKushayb'), (ICC-02-/05 -01/07-57), Pre Trial Chamber I, Decision informing the United Nations Security Council about the lack of cooperation by the Republic of Sudan, 25 May 2010.

20 United Nations Security Council, Resolution referring situation in Darfur Sudan to ICC, (RES/1593), 31 March 2005. United Nations Security Council, Resolution referring situation in Libya to ICC, (RES/1970), 26 Feb 2011. In practice, further Tribunals were created under the auspices of the UN after the ICC became operational and the two SC Resolutions that referred the situation in Darfur, Sudan and Libya to the ICC respectively explicitly excluded UN funding for these referrals.

21 United Nations Security Council, Resolution creating the International Criminal Tribunal for the Former Yugoslavia, (RES/827), 25 May 1993 and United Nations Security Council, Resolution creating the International Criminal Tribunal for Rwanda, (RES/955), 8 November 1994. See also International Criminal Tribunal for the Former Yugoslavia, Prosecutor v. Tihomir Blaskic, Case No IT-95-14, Appeal Judgement, 29 October 1997, para. 33.

22 SeeInternationalCriminalCourt(ICC), Negotiated Relationship Agreementbetween the International Criminal Court and the United Nations, (ICC-ASP/3/Res.1), 4 October 2004, Article 17(3).

23 In that case, Article 112(2)(F) of the Statute comes into play. 
by the International Law Commission at the beginning of the Rome Statute negotiations and only emerged following a 1996 French working paper and subsequent take-up by the Preparatory Committee in 1997. ${ }^{24}$ When defining the remit of the ASP, the inclusion of non-cooperation was faced with objections. ${ }^{25}$ The drafters here missed an important opportunity to enhance certainty and to encourage consistency in the approach that can be taken by the ASP. By leaving it to State discretion, differing approaches may be put forward. Reference to the ASP may also take place in the case of a non-party which has agreed to provide assistance under Article 87(5). In essence, the solution provided for in Article 87(5)(B) is identical to the one in 87(7). The only difference is that given that a State in that position has not consented to abide by the entirety of the Rome Statute, the Court cannot make a judicial finding but canonly "inform" ${ }^{26}$ the ASP or the SC of the non-cooperation.

In addition, Article 87 does not contain a paragraph to deal with failure to co-operate by a third State which has nevertheless accepted the jurisdiction of the ICC by virtue of Article 12(3) Rome Statute. ${ }^{27}$ The latter provision, allows for any State to accept the Court's jurisdiction following a declaration, thus potentially expanding the Court's reach to States that are non-parties but choose to submit a certain set of facts to the Court's judgement.$^{28}$ In the absence of a specific provision, and given that in this case the State abides by the provisions

$24 \quad$ UN Doc. A/AC.249/L.3 (1997).

25 S. Rama Rao and Philipp Ambach, 'Assembly of States Parties: Article 112' in O. Triffterer and K. Ambos (eds.), Commentary on the Rome Statute of the ICC (Beck/Hart, Nomos, Munich, 2016), 2226.

26 The choice of language is significant here. Stronger language is avoided so as not to impinge upon the rights of third parties which have chosen to provide assistance to the ICC. See Annalisa Ciampi, 'The Obligation to Cooperate', in A. Cassese, P. Gaeta, J.R.D.W. Jones (eds.), The Rome Statute of the International Criminal Court, (Oxford University Press, Ox- ford, 2002), 1633. See also Claus Kreß and Kimberly Prost, 'Article 87: Requests for Coop- eration: General Provisions', in O. Triffterer and K. Ambos (eds.), ibid., 2037, who_also raises the issue whether in case of SC referral the ASP may be informed alongside the SC of the third State's non-co-operation, and correctly conclude that Article 12 of the UN Charter does not apply to the relationship between the ASP and the SC.

27 Article 12(3), RomeStatute.

28 State of Palestine, Declaration accepting the Jurisdiction of the International Criminal Court, 31 December 2014, www.icc-cpi.int/iccdocs/PIDS/press/PalestinE_A_12-3.PDF, accessed 29 July 2019. International Criminal Court, Registrar confirms that the Republic of Côte d'Ivoire has accepted the jurisdiction of the Court, 2005, https://asp.icc-cpi.int/ en_menus/asp/press\%20releases/press\%20releases\%202005/Pages/registrar\%20confirms $\% 20$ that $\% 20$ the $\% 20$ republic $\% 20$ of $\% 20 \mathrm{c} \% 20 \_\% 20$ te $\% 20 \mathrm{~d} \% 20 \_\% 20$ ivoire $\% 20$ has\%20accepted\%20the\%20juris.aspx, accessed 29 July 2019. Ukraine, Declaration of the 
of the Statute for the purposes of a particular case, its rights and duties are equated with those of States parties. Article 87(7) of the Rome Statute would therefore apply.

Intergovernmental organisations, on the other hand, are not under a general obligation to co-operate and are only required to cooperate insofar as their mandate allows. As will be seen below, Article 112(2)(F) of the Statute, which discusses referral to the ASP, does not mention intergovernmental organisations. This omission should not be taken however to mean that once such an organisation has undertaken an explicit obligation to cooperate, it is not bound by it. ${ }^{29}$ Cooperation ought to be provided, within the limits of its man- date and the constraints of the undertaken obligation.

The above provisions set the parameters within the Statute for tackling noncooperation. The second piece of the puzzle is the operationalisation of this framework and this is through the jurisprudence of the Court as well as the measures to be adopted at the procedure followed by the ASP. It is not within the remit of the Court, to adopt measures that go beyond judicial findings, as this would exceed the role and functions of a judicial institution. Equally, referrals to the ASP and/or the SC for further measures, in light of their mandate, is an issue of governance as discussed. Both will be examined in turn.

\section{The Judicial Findings of Non-cooperation: Insights from the Jurisprudence}

In recent years, there has been a wealth of jurisprudence pertaining to noncooperation. ${ }^{30}$ With the exception of the Gaddafi $i^{31}$ and the Kenyatta ${ }^{32}$

jurisdiction of the International Criminal Court by Ukraine, 4 February 2015, www.icc-cpi .int/iccdocs/other/UkrAINE_ART_12-3_DECLARATION_08092015.PDF, accessed 29 July 2019.

29 In that sense, the Blaškić decision, supra note 21, at para. 33, could be used here as well.

30 The ASP website helpfully compiles a list of such decisions, which albeit incomplete, as a good starting point for further analysis: asp.icc-cpi.int/en_menus/asp/non-cooperation/ Pages/default.aspx, accessed 30 July 2019.

31 ICC, Prosecutorv. Saif Al-Islam Gaddafi, Decision on thenon-compliance by Libya with requests for cooperation by the Court and referring the matter to the United Nations Security Council, Pre-trial Chamber I, ICC-01/11-01/11, 10 December 2014. Interestingly, besides the surrender of Gaddafi to the Court, this case also pertains to the return to his Defence counsel of privileged documents seized by the Libyan authorities.

32 ICC, Prosecutor v. Uhuru Muigai Kenyatta, Second decision on Prosecution's application for a finding of non-compliance under Article 87(7) of the Statute, Trial Chamber v(B), ICC-01/09-02/11, 19 September 2016. See also Lorraine Smith-van Lin, 'Non-compliance 
decisions, which pertain to the Libya and Kenya situations respectively, all other non-cooperation decisions involve the situation in Sudan and cover either Sudan's non-cooperation or other State Parties' failure to arrest or sur- render persons against whom arrest warrants have been issued by the Court.

Most of the decisions relate to whether or not Al Bashir enjoys head of state immunity, which is claimed by the non-cooperating State to be a bar to arrest/ surrender and rejected by the ICC, albeit based on differing justifications. ${ }^{33}$

and the Law and Politics of State Cooperation: Lessons from the Al Bashir and Kenyatta Cases', in O. Bekou and D. Birkett (eds.) Cooperation and the International Criminal Court, Perspectives from Theory and Practice (Brill Nijhoff, Leiden, 2016), 114-151.

33 E.g. in the ICC, Prosecutor v. Omar Hassan Ahmad Al Bashir, Corrigendum to the Decision Pursuant to Article 87(7) of the Rome Statute on the Failure by the Republic of Malawi to comply with the Cooperation Requests Issued by the Court with Respect to the Arrest and Surrender of Omar Hassan Ahmad Al Bashir, Pre-Trial Chamber I, ICC-02/05-01/09, 13 December 2011. Pre-Trial Chamber I advances five arguments to reject Malawi's position: first, that international courts have since World War I rejected head of state immunity (para. 38); second, that Head of State prosecutions have increased in the past decade (para. 39); third, that the then 120 State party membership of the ICC indicates that states accept the stripping of immunity in international law from top officials (para. 40); fourth, in line with the purpose of the Statute for the Court to exercise 'its jurisdiction over persons for the most serious crimes of international concern', not surrendering Al Bashir on immunity grounds would be contrary to the above purpose (para.41). Finally, owing to the international community's commitment to rejecting immunity, 'it is no longer appropriate to say that the customary international law on immunity applies in the present context'. (para. 42). For criticism of the decision, see Dapo Akande, 'ICC Is- sues Detailed Decision on Bashir's Immunity (... At long Last...) But Gets the Law Wrong', EJIL: Talk!, 15 December 2011, https://www.ejiltalk.org/iccissues-detailed-decision

-on-bashir\%E2\%80\%99s-immunity-at-long-last-but-gets-the-law-wrong/, accessed 31 July 2019; Dov Jacobs, 'A Sad Hommage to Antonio Cassese: The ICC's confused pronouncements on State Compliance and Head of State Immunity', Spreading the Jam, 15 December 2011, https://dovjacobs.Com/2011/12/15/A-sad-hommage-to-antoniocassese- the-iccs-confused-pronouncements-on-state-compliance-and-head-of-stateimmunity/, accessed 31 July 2019. The same reasoning as in the Malawi Decision is recalled and reiterated in the ICC, Prosecutor v. Omar Hassan Ahmad Al Bashir, Decision pursuant to article 87(7) of the Rome Statute on the refusal of the Republic of Chad to comply with the co- operation requests issued by the Court with respect to the arrest and surrender of Omar Hassan Ahmad Al Bashir, Pre-Trial Chamber I, ICC-02/05-01/09 13 December 2011, parA.13. Similarly, in a second decision involving Chad, ICC, Prosecutor v. Omar Hassan Ahmad Al Bashir, decision on the Non-compliance of the Republic of Chad with the Cooperation Requests Issued by the Court Regarding the Arrest and Surrender of Omar Hassan Ahmad Al-Bashir, Pre-Trial Chamber II, ICC-02/05-01/09, 26 March 2013. In para. 21, PTC II uses harsher language to describe Chad's consistent pattern of disregarding the ICC's decisions as well as Security Council Resolution 1593 (2005), calling upon the Security Council to 
Nevertheless, the relevant case-law offers good insights as to how the Court operationalises through its findings on non-cooperation the Rome system of justice. The early jurisprudence does not really go into the merits of the arguments put forward by the State which does not comply with a cooperation request issued by the Court. ${ }^{34}$ The shift came with the Malawi Decision, ${ }^{35}$ and

take the necessary measures it deems appropriate. In the DRC non-cooperation Decision, ICC, Prosecutor v. Omar Hassan Ahmad Al Bashir, Decision on the Cooperation of the Democratic Republic of the Congo Regarding Omar Al Bashir's Arrest and Surrender to the Court, Pre-Trial Chamber II, ICC-02/05-01/09, 9 April 2014. The justification on why immunities do not apply is completely different and relies on an implicit waiver of immunities by the Security Council (para. 29). The same justification is used in the Djibouti non-cooperation decision, ICC, Prosecutor v. Omar Hassan Ahmad Al Bashir, Decision on the non-compliance by the Republic of Djibouti with the request to arrest and surrender Omar Al-Bashir to the Court and referring the matter to the United Nations Security Council and the Assembly of the State Parties to the Rome Statute, Pre-Trial Chamber II, ICC-02/05-01/09, 11 July 2016 (para. 11). Where it is also stated that immunities having been lifted by the use of Chapter VII of the UN Charter, are not an impediment at the horizontal level between a State Party and Sudan (parA.12). The same justification is also used in the Ugandan non-cooperation decision. See ICC, Prosecutor v. Omar Hassan Ahmad Al Bashir, Decision on the non-compliance by the Republic of Uganda with the request to arrest and surrender Omar Al-Bashir to the Court and referring the matter to the United Nations Security Council and the Assembly of State Parties to the Rome Statute, Pre-Trial Chamber II, ICC-02/05-01/19, 11 July 2016 (paras. 11-12). See also, Dapo Akande, 'The immunity of Heads of States of Nonparties in the early Years of the ICC', 112 AJIL Unbound (2018) 172-176, DoI.ORG/10.1017/aju.2018.56, accessed 31 July 2019.

34 Seee.g. ICc, Prosecutorv.Omar Hassan AhmadAlBashir, Decision informing the United Nations Security Council and the Assembly of the States Parties to the Rome Statute about Omar Al-Bashir's presence in the territory of the Republic of Kenya, Pretrial Chamber I, ICC-02/05-01/09, 27 August 2010; ICC, Prosecutor v. Omar Hassan Ahmad Al Bashir, Decision informing the United Nations Security Council and the Assembly of the States Parties to the Rome Statute aboutOmar Al-Bashir's recent visit to the Republic of Chad, Pre-Trial Chamber I, ICC-02/05-01/09 27 August 2010; ICC, Prosecutor v. Omar Has- san Ahmad Al Bashir, Decision informing the United Nations Security Council and the Assembly of the States Parties to the Rome Statute aboutOmar Al-Bashir's recent visit to Djibouti, Pre-Trial Chamber I, ICC-02/05-01/09 12, May 2011 and to some extent also ICC, Prosecutor v. Omar Hassan Ahmad Al Bashir, decision on the Non-compliance of the Re- public of Chad with the Cooperation Requests Issued by the Court Regarding the Arrest and Surrender of Omar Hassan Ahmad Al-Bashir, Pre-Trial Chamber II, ICC-02/05-01/09, 26 March 201; and ICC, Prosecutor v. Abdhallah Banda Abakaer Nourain, Decision on the Prosecutor's Request for a Finding of NonCompliance, Trial chamberIV, ICC-02/05

-03/09 19 November 2015.

35 ICC, Prosecutor v. Omar Hassan Ahmad Al Bashir, Corrigendum to the Decision Pursuant to Article 87(7) of the Rome Statute on the Failure by the Republic of Malawi to comply 
in terms of rigorous legal reasoning, culminated with the Pre-Trial Chamber II's decision in the case involving South Africa's non-cooperation, ${ }^{36}$ as well as the appeal in the Jordan case, ${ }^{37}$ both of which have been the subject of fierce

with the Cooperation Requests Issued by the Court with Respect to the Arrest and Surrender of Omar Hassan Ahmad Al Bashir, Pre-Trial Chamber I, ICC-02/05-01/09, 13 December 2011.

36 ICC, Prosecutor v.Al-Bashir, Decision under Article 87(7) of the Rome Statute on the Noncompliance by South Africa with the Request by the Court for the Arrest and Surrender of Omar Al-Bashir, International Criminal Court, ICC-02/05-01/09-302, Pre-Trial Chamber II, July 6,2017. In that Decision, the Chamberheld that Al-Bashir didnotenjoy immunity because the Security Council's referral placed Sudan in a similarposition as a StateParty, with Article 27(2)RomeStatutenotbeing abartotheCourt's exercise of Jurisdiction. See also Manuel J Ventura, 'International Decisions', 111(4) American Journal of International Law, 2018, 1007-1013. ICC, Prosecutor v. Al-Bashir, ICC-02/05-01/09-302, Decision Under Article 87(7) of the Rome Statute on the Non-compliance by South Africa with the Request by the Court for the Arrest and Surrender of Omar Al-Bashir, Pre-Trial Chamber II, July 6, 2017, www.icc-cpi.int/Pages/record.aspx?docNo=ICC-02/05-01/09-302, accessed 31 July 2019. See also Abel Knottnerus, 'The Immunity of al-Bashir: The Latest Turn in the Jurisprudence of the ICC',EJIL: Talk!, 15 November 2017, www.ejiltalk.org/the-immunityof-al-bashir-the-latest-turn-in-the-jurisprudence-of-the-icc/, accessed 30 July 2019; Matt Killingsworth, 'ICC ruling on South Africa and al-Bashir: Pragmatism wins the Day', The Conversation, 27 July 2017, theconversation.com/icc-ruling-on-south-africa-and-al-bashir -pragmatism-wins-the-day-81500, accessed 30 July 2019; Windell Nortje, 'South Africa's Refusal to Arrest Omar Al-Bashir', FICHL Policy Brief Series No. 85 2017, www.toaep.org/ pbs-PDF/85-NORTJE/, accessed 30 July 2019.

37 ICC, Prosecutor v. Omar Hassan Ahmad Al-Bashir, Judgment in the Jordan Referral re Al-Bashir Appeal ICC-02/05-01/09 OA2, 6 May 2019. See Alexandre Skander Galand, 'A hidden Reading of the ICC Appeals Chamber's Judgment in the Jordan Referral re AlBashir', EJILTalk!, 6 June 2019, www.ejiltalk.org/a-hidden-reading-of-the-icc-appeals -chambers-judgment-in-the-jordan-referral-re-al-bashir/, accessed 30 July 2019; 'ICC reverses Jordan Non-Cooperation Referral for Failure to Arrest Al-Bashir', 10 May 2019, ijrcenter.ORG/2019/05/10/ICC-Reverses-jordan-non-cooperation-referral-for-failure-to -arrest-al-bashir/, accessed 30 July 2019; Kevin J. Heller, 'A Thought Experiment about Complementarity and the Jordan Appeal Decision', 9 May 2019, Opinio Juris, opiniojuris. org/2019/05/09/a-thought-experiment-about-complementarity-and-the-jordan-appeal -decision/, accessed 30 July 2019; Dapo Akande, 'ICC Appeals Chamber holds that heads of State have no Immunity under Customary International Law before International Tribunals', EJILTalk!, www.ejiltalk.org/icc-appeals-chamber-holds-that-heads-of-state -have-no-immunity-under-customary-international-law-before-international-tribunals/, accessed 30 July 2019; Leila N. Sadat, 'Heads of State and Other Government Officials Before the International Criminal Court: The Uneasy Revolution Continues', January 23, 2019, (in M. DeGuzman and V. Oosterveld (eds.), The Elgar Companion to the International Criminal Court, (Elgar, Cheltenham, forthcoming,) Washington University St. Louis Legal 
academic scrutiny. Whilst, important, the divergent jurisprudence on whether or not immunities apply, is however outside the scope of the presentpiece, which focuses on non-cooperation per se. As such, the Court's jurisprudence is looked at through the lens of the findings on (non)cooperation, with the underlying legal basis on which findings are made, e.g. the merits of immunities, being immaterial for the present piece.

Returning on what the jurisprudence can tell us about how the Court has dealt with instances of non-cooperation, decisions that are directed at Sudan for its own lack of cooperation, are short, mention the cooperation obligations stemming from Security Council Resolution 1593 and in the findings refer the matter to the Security Council through the Secretary General. ${ }^{38}$ Curiously, in the early non-cooperation decisions the task of transmitting the decision to the Security Council was left to the ICC's Registrar ${ }^{39}$ whereas from the Malawi

Studies Research Paper No. 19-01-12, ssrn.com/abstraCT=3321998 or DX.DOI.ORG/10.2139/ SSRN.3321998; Dov Jacobs, 'You have just entered Narnia: ICC Appeals Chamber adopts the worst possible Solution on Immunities in the Bashir Case', Spreading the Jam, 6 May 2019, dovjacobs.com/2019/05/06/You-have-just-entered-narnia-icc-appeals-chamber-adopts -the-worst-possible-solution-on-immunities-in-the-bashir-case/, accessed 30 July 2019; Ben Batros, 'A confusing ICC Appeals Judgment on Head-of-State Immunity', Just Security, 07 May 2019, www.justsecurity.org/63962/a-confusing-icc-appeals-judgmenton-head-of-state-immunity/, accessed 30 July 2019; Asad Kiyani, 'Elisions and Omissions: Questioning the ICC's latest Bashir Immunity Ruling, Just Security', 8 May 2019, www.just- security.org/63973/elisions-and-omissions-questioning-the-iccs-latest-bashirimmunity-ruling/, accessed 30 July 2019; Leila Sadat, 'Why the ICC's Judgment in the AlBashir Case wasn't so Surprising, Just Security, 12 July 2019, www.justsecurity.org/64896/why-the-iccs-judgment-in-the-al-bashir-case-wasnt-sosurprising/, accessed 30 July 2019; Claus Kreß, 'Preliminary Observations on the ICC Appeals Chamber's Judgment of 6 May 2019 in the Jordan Referral re Al-Bashir Appeal', Occasional Paper Series, TOAEP, 2019, www.toaep.org/ops-pdf/8-kress, accessed 30 July 2019.

38 ICC, Prosecutor v.Ahmad Muhammad Harun ('Ahmad Harun') and Ali Muhammad Ali Abd-Al-Rahman ('Ali Kushayb'), Decision informing the United Nations Security Council about the lack of cooperation by the Republic of Sudan, ICC-02/05-01/07, 25 May 2010. See also: ICC, Prosecutor v. Omar Hassan Ahmad Al Bashir, Decision on the Prosecutor's Request for a Finding of Non-Compliance Against the Republic of the Sudan, Pre-Trial Chamber II, ICC-02/05-01/09, 9 March 2015; ICC, Prosecutor v. Abdel Raheem Muhammad Hussein, Decisionon theProsecutor'srequestforafinding ofnon-complianceagainst the Republic of the Sudan, Pre-Trial Chamber II, ICC-02/05-01/12, 26 June 2015.

39 Ibid. ICC, Prosecutor v. Ahmad Muhammad Harun ('Ahmad Harun') and Ali Muhammad Ali Abd-Al-Rahman ('Ali Kushayb'), Decision informing the United Nations Security Council about the lack of cooperation by the Republic of Sudan, ICC-02/05-01/07, 25 May 2010; ICC, Prosecutor v. Omar Hassan Ahmad Al Bashir, Decision informing the United Nations 
decision onwards, transmission to the Security Council has been entrusted to the ICC's President for onward transmission. ${ }^{40}$ The transfer of this task to the Presidency, although not explained by the Chambers, adds significant political weight to the legal finding and elevates it from an administrative task by removing it from the Registry.

Given that the purpose of Article 87(7) is to 'foster cooperation," whether the Chamber informs the ASP is discretionary; as is the referral to the Security Council of a finding of non-cooperation.42 In the Jordan appeal, such a referral was successfully reversed. ${ }^{43}$

The jurisprudence also places emphasis on the importance of entering into consultations with the Court. ${ }^{44}$ This is a determinant factor as to whether or not a State is seen to be engaging with the Court. ${ }^{45}$ As there is no prescribed

Security Council and the Assembly of the States Parties to the Rome Statute about Omar Al-Bashir's presence in the territory of the Republic of Kenya, Pre-Trial Chamber I, ICC02/05-01/09, 27 August 2010; ICC, Prosecutor v. Omar Hassan Ahmad Al Bashir, Decision informing the United Nations Security Council and the Assembly of the States Parties to the Rome Statute about Omar Al-Bashir's recent visit to the Republic of Chad, Pre-Trial Chamber I, ICC-02/05-01/09 27 August 2010; ICC, Prosecutor v. Omar Hassan Ahmad Al Bashir, Decision informing the United Nations Security Council and the Assembly of the States Parties to the Rome Statute about Omar Al-Bashir's recent visit to Djibouti, PreTrial Chamber I, ICC-02/05-01/09 12, May 2011.

40 ICC, Prosecutor v. Omar Hassan Ahmad Al Bashir, Corrigendum to the Decision Pursuant to Article 87(7) of the Rome Statute on the Failure by the Republic of Malawi to comply with the Cooperation Requests Issued by the Court with Respect to the Arrest and Surrender of Omar Hassan Ahmad Al Bashir, Pre-Trial Chamber I, ICC-02/0501/09, 13 December 2011, pursuant to International Criminal Court, Regulations of the Court, ICC-BD/01-01-04, Regulation 109(4).

41 ICC, Prosecutorv. Uhuru Muigai Kenyatta, Judgment on the Prosecutor's appeal against Trial Chamber v(B)'s 'Decision on Prosecution's application for a finding of non-compliance under Article 87(7) of the Statute', Appeals Chamber,ICC-01/09-02/11 OA5, 19 August2015, para. 51.

42 Ibid., paras. 49,64.

43 ICC, Prosecutor v. Omar Hassan Ahmad Al-Bashir, Judgment in the Jordan Referral re Al-Bashir Appeal ICC-02/05-01/09 OA2, 6 May 2019, para. 216, Judges Ibáñez and Bossa dissenting.

44 Pursuant to Article 97, Rome Statute.

45 The decision in South Africa very much hinged on this issue. ICC, Prosecutor v. Al-Bashir, DecisionUnderArticle 87(7)oftheRomeStatuteon theNon-complianceby South Africa with the Request by the Court for the Arrest and Surrender of Omar Al-Bashir, International Criminal Court, ICC-02/05-01/09-302, Pre-Trial Chamber II, July 6, 2017, paras. 127 onwards. 
procedure to be followed, the manner in which a State can show its intentions to engage in consultations may vary. ${ }^{46}$ What is required however, is that such an intention is clear. ${ }^{47}$ Indeed, approaching the ICC with a request for consultations, is an important factor for the Court not to make a referral for non-compliance. ${ }^{48}$

One would expect that the Security Council would respond with appropriate measures when referral to the Council occurs following a finding of non- cooperation. As the Court has observed on the lack of follow-up action 'any referral by Council to the ICC under Chapter VII would never achieve its ultimate goal, namely, to put an end to impunity. Accordingly, any such referral would become futile. ${ }^{49}$ To date, and irrespective of the above stark warning, no action has been taken by the Security Council following a referral to it of a finding of non-cooperation by the Court.

The ICC through its jurisprudence also addressed, albeit in passing, what cannot be relied upon in order to relieve a State of their obligations to cooperate. In that sense, recent visits by the person whose arrest is sought to other States and absence of arrests elsewhere, cannot be relied upon to evade an obligation to arrest and surrender. ${ }^{50}$ Similarly, the absence of relevant national legislation cannot serve as a justification for non-compliance with the request for cooperation by the Court under Part 9 of the Statute. ${ }^{. l}$ Moreover, although the Court may acknowledge that a volatile political situation exists, this is not a reason not to

46 ICC, Prosecutor v. Omar Hassan Ahmad Al-Bashir, Judgment in the Jordan Referral re AlBashir Appeal ICC-02/05-01/09 OA2, 6 May 2019, para. 201.

47 Ibid., para. 204.

48 ICC, Prosecutor v. Al-Bashir, Decision Under Article 87(7) of the Rome Statute on the Noncompliance by South Africa with the Request by the Court for the Arrest and Surrender of Omar Al-Bashir, International Criminal Court, ICC-02/05-01/09-302, Pre-Trial Chamber II, July 6, 2017, para. 127.

49 ICC, Prosecutor v. Omar Hassan Ahmad Al Bashir, Decision on the Non-compliance of the Republic of Chad with the Cooperation Requests Issued by the Court Regarding the Arrest and Surrender of Omar Hassan Ahmad Al-Bashir, Pre-Trial Chamber II, ICC-02/05 -01/09, 26 March 2013, para.22; See also ICC, Prosecutor v. Omar Hassan Ahmad Al Bashir, Decision on the Cooperation of the Democratic Republic of the Congo Regarding Omar Al Bashir's Arrest and Surrender to the Court, Pre-Trial Chamber II, ICC-02/05-01/09, 9 April 2014, para. 33.

50 Ibid., para. 21.

51 ICC, Prosecutor v. Omar Hassan Ahmad Al Bashir, Decision on the non-compliance by the Republic of Djibouti with the request to arrest and surrender Omar Al-Bashir to the Court and referring the matter to the United Nations Security Council and the Assembly of the State Parties to the Rome Statute, Pre-Trial Chamber II, ICC-02/05-01/09, 11 July 2016, para. 10. 
execute a cooperation request, ${ }^{52}$ and neither is a quest for peace and stability a bar to arrest/surrender. In a few of the cases, State Parties have been reminded that the pursuance of legitimate or desirable political objectives should occur within the boundaries of their legal obligations vis-à-vis the Court, but suchlegal obligations cannot be putaside or qualified for political expediency. ${ }^{53}$

Overall, it is questionable whether the ICC's jurisprudence on noncooperation has made any discernible difference. Although it has been argued that blaming and shaming may have an important deterrent effect, ${ }^{54}$ as well as some political impact, ${ }^{55}$ the fact remains that it has not stopped international travel of persons indicted by the Court nor State non-cooperation. This does not detract from the importance of the decisions in terms of their legal weight. However, to effectively address non-cooperation, relying on judicial findings alone is not enough, particularly where the jurisprudence is inconsistent in terms of approach to the legal and procedural issues raised, or because it is not backed up by subsequent action. An examination of the role and procedure before the ASP is therefore necessary as a means of complementing the judicial findings rendered by the Court.

\section{The ASP as a Vehicle for Tackling Non-cooperation}

Article 112(2)(F) Rome Statute provides the mechanism for dealing with nonco-operation. ${ }^{56}$ Accordingly, the ASP is entitled to request the compliance of the recalcitrant State and may condemn its failure to co-operate.

52 ICC, Prosecutorv.Saif Al-Islam Gaddafi, Decision on thenon-compliance by Libya with requests for cooperation by the Court and referring the matter to the United Nations Security Council, Pre-trialChamber I, ICC-01/11-01/11,10December 2014, para. 32.

53 ICC, Prosecutor v. Omar Hassan Ahmad Al Bashir, Decision on the non-compliance by the Republic of Uganda with the request to arrest and surrender Omar Al-Bashir to the Court and referring the matter to the United Nations Security Counciland the Assemblyof State Parties to the Rome Statute, Pre-Trial Chamber II, ICC-02/05-01/19, 11 July 2016, para. 14. ICC, Prosecutor v. Omar Hassan Ahmad Al Bashir, Decision on the non-compliance by the Republic ofDjiboutiwith therequest toarrestand surrenderOmarAl-BashirtotheCourtand referring the matter to the United Nations Security Council and the Assembly of the State Parties to the Rome Statute, Pre-Trial Chamber II, ICC-02/05-01/09, 11 July 2016, para. 14.

54 ICC, Prosecutorv. Omar Hassan Ahmad Al-Bashir, Amicus curiae observations of Prof. Annalisa Ciampipursuant to Rule 103 of the Rules of Procedure andEvidence, ICC-02/05 $-01 / 09,18$ June 2018, p. 12.

55 Transcript of hearing, 13 September 2018, ICC-02/05-01/09-T-7-ENG, p. 75, line 22- p. 76, line 1.

56 Article 112(2)(F) Rome Statute states: 'The Assembly shall: Consider pursuant to article 87, paragraphs 5 and 7 , any question relating to non-cooperation'. 
Although adopting countermeasures should not be precluded as a theoretically available option, ${ }^{57}$ it would be a radical one. Needless to say, this has not been used to date. Failure to co-operate with the ICC entails international responsibility for the State concerned; it amounts to a breach of an obligation arising out of an international treaty. Such a breach is an internationally wrongful act, which in turn, gives rise to State responsibility in international law. ${ }^{58}$ However, a finding of State responsibility will not assist in securing cooperation with the Court in practice. The ICC as a criminal justice institution, was created by a treaty and that non-cooperation is a breach of this treaty. However, the Rome Statute differs from other international treaties in that owing to the criminal nature of the institution, repercussions on issues of fairness for the accused ought to be considered when measures tackling a breach of such a treaty are being examined.

From a treaty law perspective, termination of the treaty with regard to the noncomplying State would have been the expected course of action. ${ }^{59} \mathrm{Kre} ß$ and Prost, however, note that this should not be an option "given [the Statute's] integral nature and its overall humanitarian goal" ${ }^{60}$ Indeed, the Rome Statute, albeit an international treaty, has a distinct character and application from that of normal treaty rules. In case of non-co-operation, it is in the interests of both the ICC and its parties to force the non-complying State to fulfil its obligations under the treaty. And this cannot be achieved by terminating the treaty for the said party.

Another issue which then arises is whether and to what extent a State party is entitled to act individually to tackle failure to cooperate. Articles 87(7) and 112(2)(F) Rome Statute, intimate that collective action is the preferred option. It is not clear if a State may engage in individual action if the ASP does not reach the majority necessary to take action against the non-cooperating State.

57 Countermeasures may take the form of economic sanctions. See Nigel White, and Ademola Abass, 'Countermeasures and Sanctions', in M. Evans (ed.), International Law, (Oxford University Press, Oxford, 2014), 508.

58 International Law Commission, Articles on State Responsibility of States for Internationally Wrongful Acts, Report of the International Law Commission, Fifty-third Session (A/56/10, 10 August 2001). For a commentary on these Articles see James Crawford, Commentary on Articles on State Responsibility for Internationally Wrongful Acts (Cambridge University Press, Cambridge, 2002), 74-90.

59 United Nations, Vienna Convention on the Law of Treaties between States and International Organizations or between International Organizations, (A/CONF.129/15, 21 March 1986), Article 60.

60 Kreß and Prost, supra note 26, 2042. 
Customary law would not preclude such action ${ }^{61}$ although the right to take counter-measures is generally confined to the "injured" State. It is hard to determine on what basis such action could be rationalised and consequently, no satisfactory solution can be put forward.

Similarly, of interest might be whether the SC could intervene and adopt measures to tackle the failure to cooperate by a particular State, in a case which did not originate from a SC referral. ${ }^{62}$ Although this possibility is not mentioned in the Statute, it is legally possible for the SC to step in when the situation amounts to a threat or breach of the peace. Given the reluctance and inaction demonstrated by the $\mathrm{SC}$ even when $\mathrm{SC}$ intervention is merited, the chances of such a SC action in practice are pretty small.

Moving to examine the procedure to be followed by the ASP when faced with non-cooperation, this was adopted at the $10 \mathrm{TH}$ meeting of the ASP in $2011 .{ }^{63} \mathrm{The}$ ASP recognises that "... any response by the Assembly would be non-judicial in nature." ${ }^{64}$ The role of the ASP is limited to deploying political and diplomatic efforts that run alongside, and do not replace, judicial determinations in proceedings before the Court. ${ }^{65}$

The ASP may become involved in two disparate scenarios: Firstly, where the Court has referred a matter of non-cooperation to it 66 and secondly, where the Court might not yet have referred a matter of non-cooperation to the Assembly, but there are reasons to believe that a specific and serious incident of

61 There is also a view which requests that the individual action does not go beyond the Assembly's recommendations. Following this approach, no individual action would be accepted should the Assembly of States make no recommendation to that effect. See Kreß, and Prost, supra note 26.

62 This possibility is examined by Antonio Cassese, Cassese's International Criminal Law, 3rd ed. (Oxford University Press, Oxford, 2013), 307.

63 International Criminal Court, Strengthening the International Criminal Court and the Assembly of States Parties (Resolution ICC-ASP/10/Res.5), 21 December 2011. Amended by International Criminal Court, Strengthening the International Criminal Court and the Assembly of States Parties, (ICC-ASP/11/Res.8, annex I), 21 December 2012.

64 International Criminal Court, Strengthening the International Criminal Court and the Assembly of States Parties(ResolutionICC-ASP/10/Res.5), 21 December2011,p.39, para. 6 .

65 'The Assembly may certainly support the effectiveness of the Rome Statute by deploying political and diplomatic efforts to promote cooperation and to respond to non- cooperation. These efforts, however, may not replace judicial determinations to be taken by the Court in ongoing proceedings'. International Criminal Court, Assembly procedures relating to non-cooperation, (ICC-ASP/10/Res.5, annex), 21 December 2011, p. 39 , para. 6 .

66 International Criminal Court, Strengthening the International Criminal Court and the Assembly of States Parties, (ICC-ASP/10/Res.5, annex, amended by ICC-ASP/11/Res.8, annex), p. 39, para. 7 . 
non-cooperation in respect of a request for arrest and surrender of a person (Article 89 of the Rome Statute) is about to occur or is currently ongoing. ${ }^{67}$ This latter scenario only engages exceptionally.

The Resolution identifies two types of procedure: a formal response procedure and an informal one. The former outlines successive steps to be taken by the Bureau and the Assembly, which are as follows: ${ }^{68}$

First, there is an emergency meeting of the Bureau of the Assembly. Following that, the President of the Assembly addresses an open letter to the State concerned. This letter reminds the concerned State of its obligation to cooper- ate with the court and requests its views on the relevant matter, within a specific time frame. If the above-mentioned time limit expires or the concerned state issues a written response, a meeting of the Bureau may be held whereby the concerned State is invited to provide its views. Furthermore, the Bureau may request a public meeting of the New York Working Group to be held to discuss the matter. Following on from this, a Bureau report on the outcome of this dialogue may be submitted to the next session of the Assembly, this may include any recommendations as to future action required. This report may subsequently be discussed at the next session of the Assembly. Moreover, the Bureau could appoint a facilitator to consult_on a draft resolutions and recommendations on the matter. The above procedure may be perceived as formalistic. Although in terms of ICC governance structure it makes sense, in practice it is not very agile, nor is it able to respond quickly to a fast-developing situation which calls for immediate action. Discussions at the cooperation segment of the ASP, now a standing item, take place usually after the event and are often divisive owing to States' allegiances with the position adopted by regional groupings and laden with inflammatory statements often aimed at scoring points. ${ }^{69}$

The informal response procedure, however, aims to build on the good offices by the President of the Assembly. ${ }^{70}$ The President of the Assembly would therefore act on his or her own initiative. Where appropriate, he or she would raise the issue informally and directly with officials from the requested State, and other relevant stakeholders. ${ }^{71}$ The aim of such an approach would be to promote full cooperation. During this interaction, the President may remind the concerned state of the possibility under Article 97 (Rome Statute) to

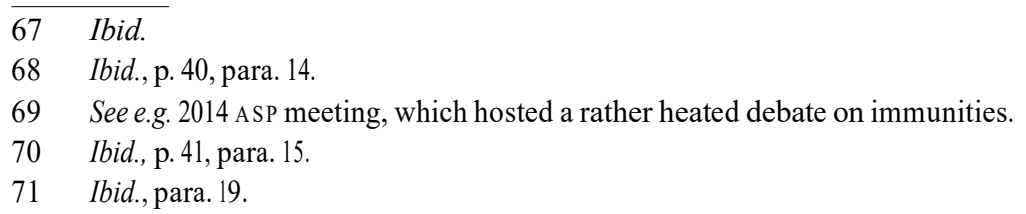


consult with the Court. Additionally, the President may also request any regional focal points, or any other Bureau member to provide assistance in this interaction.

A closer look at the application of the above procedure shows that it has not been wholly successful. ${ }^{72}$ Most of the action has been 'soft action' taken by the ASP president. For instance, when the office of the ASP president receives information that a person whose arrest is sought by the ICC is planning a visit to a State Party, then upon verification of such information with the State concerned and with other relevant stakeholders, he/she notifies State Parties, Ob- server States as well as civil society organisations with the view to them joining efforts to prevent instances of non-cooperation. ${ }^{73}$ In addition, when the focal points also receive information about possible travel of persons subject to ICC arrest warrants, this is then shared with the Court. ${ }^{74}$

On occasion, the New York Working group has met informally to discuss non-cooperation, ${ }^{75}$ but action has been mostly limited to dialogue ${ }^{76}$ letters addressed to States whose cooperation is sought, demarches (including press releases and social media statements) by the ASP president and other State Parties to try and ensure cooperation. ${ }^{17}$ The actions can be useful

72 Göran Sluiter and Stanislas Talontsi, 'Credible and Authoritative Enforcement of State Cooperation with the International Criminal Court', in Bekou and Birkett (eds.), supra note 32, p. 108 .

73 For example, the ASP president has sent such messages, see Assembly of States Parties, Report of the Bureau on non-cooperation, ICC-ASP/12/34, 2013 paras. 9-10; Assembly of States Parties, Report of the Bureau on non-cooperation, ICC-ASP/13/40, 2014, paras. 18-20; Assembly of States Parties, Report of the Bureau on non-cooperation, ICC-ASP/14/38, 2015, paras. 27-28.

74 See Assembly of States Parties, Report of the Bureau on non-cooperation, ICC-ASP/14/38, 2015, para. 33; Assembly of States Parties, Report of the Bureau on non-cooperation, ICC-ASP/15/31, 2016, paras. 23-24; Assembly of States Parties, Report of the Bureau on non-cooperation, ICC-ASP/16/36, 2017, paras. 22-23; Assembly of States Parties, Report of the Bureau on non-cooperation, ICC-ASP/17/31, 2018, paras. 31-32.

75 For example, in light of Al-Bashir's visit to Chad, the New York Working Group met informally in 2013 to discuss non-cooperation. At that meeting, the delegates reflected on the 'applicability and constraints of the [...] Assembly non-cooperation procedures', Assembly of States Parties, Report of the Bureau on non-cooperation, ICC-ASP/12/34, 2013, para. 13.

76 Assembly of States Parties, Report of the Bureau on non-cooperation, ICC-ASP/14/38, 2015, para. 30.

77 Assembly of States Parties, Report of the Bureau on non-cooperation, ICC-ASP/13/40, 2014, paras. 19-21. Assembly of States Parties, Report of the Bureau on non-cooperation, ICC-ASP/14/38, 2015, para. 28. 
to the extent that they provide a timely response to instances of (non)cooperation. However, the politicised nature of the ASP means that the type and intensity of the response is dependent on the particular political/regional affiliations at any given moment and cannot therefore provide a consistent nor a reliable course of action able to tackle noncooperation effectively.

In 2018, the non-cooperation focal points developed a "Toolkit for the Implementation of the informal dimension of the Assembly procedures relating to non-cooperation", ${ }^{78}$ which seeks to encourage States to meet their cooperation obligations in relation to the arrest and surrender of persons subject to a warrant of arrest. The Toolkit contains sensible practical steps that aim to nip non-cooperation in the bud. It is structured in a logical manner, following the predictable course of events. The first step involves monitoring the travel of persons subject of warrants of arrest and includes not only monitoring through the diplomatic network, but also through twitter or Google alerts. ${ }^{79}$ The Toolkit then encourages the sharing of such information widely, i.e. with the non-cooperation focal points, the ICC as well as State Parties and civil so- ciety. ${ }^{80}$ Moreover, in order to prevent instances of noncooperation, the Tool- kit contains appropriate wording for draft statements, notes verbales, talking points and media releases (including social media). ${ }^{81}$ The Toolkit then moves on to describe how to keep non-cooperation on the agenda through sensitisation of interlocutors ${ }^{82}$ before offering language that would remove ambiguity with regard to the obligation of a non-State party to cooperate, for the Security Council to use in future SC referrals to the Court. ${ }^{83}$

One might view with suspicion or even scepticism the efficacity of using Google alerts in stopping non-cooperation.$^{84}$ All things considered, the Toolkit provides a fresh approach towards both preventing as well as tackling noncooperation. Its efficacy is yet to be tested in practice. Nevertheless, it can be viewed as a welcome addition to the ASP's armoury, particularly given that all action to date has been based on the informal procedure which has so far been below expectations in terms of tangible results. In the view of this author, anything to help strengthen the (limited) effect the ASP can have in

78 SeeICC-ASP $/ 17 / 31$, AnnexIII, Toolkit for the Implementation of the informal dimension of the Assembly procedures relating to non-cooperation, 28 November 2018.

79 Ibid., section II, A and B, paras. 11-2 for the former and 13-15 for the latter.

80 Ibid., section II, C, D and E.

81 Ibid., section III.

82 Ibid., section IV.

83 Ibid., section C.

84 Contained in the Toolkit ICC-ASP/15/31/Add.1, II B. 
practice, is a step in the right direction; it does however presuppose that relevant stakeholders will become more proactive in engaging with cooperation, which is not always a given.

\section{Rethinking the Way Forward: Towards a More Holistic Approach to Tackling Non-cooperation}

Having examined the ways non-cooperation has been dealt with to date, it is important to consider what types of additional initiatives can reduce instances of non-cooperation, but also effectively deal with such instances when they occur, as well as avoid repetition in the future ${ }^{85}$ Recognising that the ICC as a global institution is inter-dependent on other actors, engaging such actors in a collective effort, is more likely to yield results, when combined with the Court's legal findings on non-cooperation.

Starting with the ICC itself, taking into account the constraints imposed by the Statute and the very judicial nature of the institution, strengthening consistency in the Court's non-cooperation findings would be key ${ }^{86}$ Whilst recognising that each case needs to be examined on its own merits and pertains to potentially different sets of facts, adopting a consistent approach both in the legal findings as well as the responses to non-cooperation, where possible, would be a good start. This would help send a coherent message to the non-cooperating State; a common approach would also help deter future non- cooperation by the same or other States.

Moving on to State parties, the focus should be on measures aimed at strengthening bilateral cooperation. Maintaining a constructive dialogue with the national authorities designated to execute cooperation requests (including law enforcement and cooperation networks and specialised war crimes units $)^{87}$ can lead to the prompt execution of ICC requests for cooperation.

85 As the representative Denmark put it in their statement at the $12 \mathrm{TH}$ Session of the Assembly of States Parties: 'Instances of non-cooperation should lead to a clear response from us as States Parties, but we should also together search for ways to avoid repetitionof suchinstancesinthefuture'.H.EAmbassadorOleE. Moseby Ambassadorof Den- mark, Statement by Denmark at the 12TH session of the Assembly of States Parties to the Rome Statute of the International Criminal Court, 20-28 November 2013, asp.icccpi.int/ iccdocs/asp_docs/ASP12/GENDEBA/ICC-ASP12-GenDeba-Danmark-ENG.pdf, accessed 30 July 2019.

86 Seesupra section 3.

87 Pascal Turlan, 'The International Criminal Court Cooperation Regime - A Practical Perspective from the Office of the Prosecutor', in Bekou and Birkett (eds.), supra note 32, p. 74. 
The human factor should not be underestimated, as it is often the existence of personal contacts within such national authorities that aids smooth cooperation in the execution of cooperation requests originating at the ICC. This is true, provided that the legal framework and political will are present.

Whereas political will is harder to predict, the key to complying with the requirement under the Statute to have procedures pertaining to cooperation available at the national level, ${ }^{88}$ is the enactment of legislation implementing the cooperation provisions. Reviewing existing national legal frameworks, examining their compatibility with the Statute and putting the procedures in place to be able to execute ICC cooperation requests is essential for the success of the Rome system of justice, as the requests for cooperation cannot be executed directly, but require national authority to do so. ${ }^{89}$ The absence of a dedicated ICC enforcement mechanism, as discussed already, means that States have to provide assistance in order to arrest/surrender alleged perpetrators, serve documents, collect evidence, and facilitate the appearance of witnesses etc. which are essential for the ICC to be able to discharge its functions. ${ }^{90}$

Linked to this is encouraging State parties to sign, ratify and implement the Agreement on Privileges and Immunities of the ICC. ${ }^{91}$ The APIC provides the ICC, officials, staff, as well as victims and witnesses, with the privileges and immunities necessary to perform their duties independently, unconditionally and efficiently ${ }^{92}$ which is also important to achieving full cooperation.

Moreover, as victim participation is one of the key attributes and innovations of the ICC ${ }^{93}$ facilitating their appearance, and ensuring their protection is equally important. ${ }^{94}$ States are encouraged to sign relocation agreements, so as to enable victims and witnesses to participate at trials before the ICC,

$88 \quad$ Article 88, RomeStatute.

89 International Criminal Law Guidelines, Case Matrix Network, September 2017, p. 13, www .legal-tools.oRG/DOC/E05157/pdf/, accessed 30 July 2019.

90 Article 93, RomeStatute.

91 See, International Criminal Court, Agreement on the Privileges and Immunities of the International Criminal Court, (ICC-ASP/1/3, henceforth 'APIC'), the APIC was adopted 9 September 2002, and entered into force 22 July 2004.

92 Ibid., APIC, Articles 13-18, and Articles 19-20.

93 Article 68, Rome Statute. T. Markus Funk, Victims' Rights and Advocacy at the International Criminal Court, 2nd ed. (Oxford University Press, Oxford, 2015).

94 For the cooperation issues that arise with regard to victims and witnesses, see AnneAurore Bertrand and Natacha Schauder, 'Practical Cooperation Challenges faced by the Registry of the International Criminal Court', in Bekou and Birkett(eds.), supra note 32, pp. 172-177. 
reducing fear and ensuring their security and confidence in choosing to testify. ${ }^{95}$ Relocation agreements contribute towards ensuring that victims and witnesses are better protected - in a suitable geographical and cultural environment that serves to guarantee both their security and confidence to ap- pear before the Court, and form part of another important aspect of the wider cooperation framework. Similarly, to complete the wider cooperation cycle, States should also consider receiving convicted detainees for the enforcement of their sentences and entering into the relevant agreements with the Court. ${ }^{96}$ As with the relocation agreements, albeit not a direct request for cooperation by the ICC, the existence of such agreements further assists in fulfilling the Court's mandate and should also be considered in this process.

The combination of implementing legislation, APIC ratification and implementation as well as agreements that offer victim protection and that allow for the enforcement of sentences, complete the legal framework created by the Rome Statute system and constitute the first step in ensuring that cooperation can be provided. However, to date, more than half of the State Parties do not have cooperation legislation, there are only seventy-seven Parties to the APIC, and just fourteen relocation agreements. ${ }^{97}$ Focusing on building capacity at

95 See, International Criminal Court, Report of the Court on Cooperation, (ICC-ASP/15/9), 11 October 2016, asp.icc-cpi.int/iccdocs/asp_docs/ASP15/ICC-ASP-15-9-ENG.pdf, accessed 30 July 2019.

96 Agreements on the enforcement of sentences are currently in force between the ICC and the governments of Argentina, Austria, Belgium, Colombia Denmark, Finland, Georgia, Mali, Norway, Serbia, Sweden and the United Kingdom of Great Britain and Northern Ireland. The agreements between Mali, Colombia and the ICC have not yet entered into force. See, International Criminal Court, Press release on agreement on sentences with Colombia, https://asp.icccpi.int/en_menus/asp/press\%20releases/press\%20releases\% 202011/Pages/icc\%20president $\% 20$ to $\% 20$ sign $\% 20$ enforcement $\% 20$ of $\% 20$ sentences $\% 20$ agreement $\% 20$ during $\% 20$ his $\% 20$ visit $\% 20$ to $\% 20$ colombia.aspx, accessed 30 July 2019 . See, InternationalCriminalCourt, WeeklyUpdate, Agreementbetween MaliandICC, Page3, https://www.icc-cpi.int/NR/rdonlyres/E2CCDBB2-0B59-42B6-82E6-B5119F96F47B/ 284209/ED112ENG.pdf, accessed 30 July 2019.

97 See information obtained through the Cooperation and Judicial Assistance Database (CJAD), available at: cjad.nottingham.ac.uk Having access to legislation from other States is of great help to those states with materially less resources. CJAD was created at the request of the Hague Working Group and acts as a central information hub on all aspects of cooperation legislation. The Court, national legislators, lawyers, prosecutors, academics and civil society organisations are able to freely access information on how States have interpreted the cooperation obligations. 
the national level to increase the availability of appropriate legal instruments is key to ensuring that the first step towards achieving cooperation is taken. ${ }^{98}$

Leaving State parties to one side, harnessing assistance by non-State Parties willing to offer support to the ICC at any given moment and with regard to a particular cooperation need helps strengthen cooperation. As discussed, with the exception of situations referred to the ICC by the SC where even nonparties are expected to cooperate, ${ }^{99}$ States non-party to the Statute are not under an obligation to cooperate with the Court. However, where voluntary cooperation by non-parties may be on offer, every effort should be made to be actively encouraged. A successful instance of such voluntary cooperation arose when the United States of America, a non-State Party to the Rome Statute, handed over LRA commander Dominic Ongwen to the authorities in the Central African Republic, who then took the decision to surrender him to the ICC for trial in The Hague. ${ }^{100}$ Such voluntary assistance by non-parties, in support of the ICC's cooperation needs, is to be cherished and further developed. Finally, it is important for the ICC to build upon its pre-existing multifaceted cooperation with intergovernmental organisations, including with the European Union (EU), the Commonwealth, human rights and humanitarian organisations, victims' associations, as well as international civil society ${ }^{101}$ more generally. This type of cooperation is important to harness much-needed international support towards the institution and ensure that cooperation is

achieved, through exercising the necessary political pressure.

Taking this a step further and whilst remaining in the political sphere, embracing a 'carrot and stick' approach, may perhaps yield some success in terms of cooperation, beyond what can be achieved through ASP action. ICTY Prosecutor Serge Brammertz when reflecting on the ICTY's experience, remarked: "...one of the lessons learned is clearly that conditionality policies have been crucial in securing the arrest of ICTY fugitives." Moreover, he maintained that "... key factor in the ICTY's clean record on fugitive arrests is the use of financial

98 See generally, Olympia Bekou, 'Building National Capacity for the ICC: Prospects and Challenges', in T.Mariniello(ed.), The International Criminal Courtin Search of Its Purpose andIdentity (Routledge, Oxon, 2015); Morten Bergsmo etal., 'Complementarity after Kampala: Capacity Building and the ICC's Legal Tools', 2 Goettigen Journal of International Law (2010) 791-811.

99 This is owing to Chapter VII obligation arising under the United Nations Charter and not under the RomeStatute.

100 International Criminal Court, Report of the Registry on the voluntary surrender ofDominic Ongwenand his transfer to the Court, 22 January 2015, ICC-02/04-01/05, https://www .icc-cpi.int/CourtRecorDs/CR2015 01648.PDF, accessed 30 July 2019.

101 See Matthew Cannock, 'Strengthening International Criminal Court Cooperation-The Role of Civil Society', in Bekou and Birkett(eds.), supra note 32, pp.318-365. 
and political incentives for states to cooperate with the ICTY."102 A similar approach with regard to fostering cooperation with the ICC SHOULD also be considered, if support to the ICC cooperation regime is to become more effective. An example of successful political pressure can be found in the EU's conditionality policies. Though focusing on encouraging ratification and implementation of the Rome Statute, such policies, if used consistently, could help ensure better cooperation with the Court. Specifically, given that all Member States of the EU are also State Parties to the Rome Statute, the EU has adopted a policy of conditionality for States wishing to join the Union. This policy requires candidate states to ratify and implement the Rome Statute as a condition for accession and helps ensure consistency across the Union. Of the candidate countries - North Macedonia, Iceland, Montenegro, Serbia, and Tur- key, only Turkey has yet to ratify the Rome Statute. In the 2019 Progress Report, this was mentioned as having affected the rate of Turkey's alignment with the EU on the common foreign and security policy. ${ }^{103}$ When continuing negotiations with current and potential future candidate States an ICC conditionality clause has the potential of achieving good results. Moving further afield, ICC clauses could be incorporated in other international agreements, as was done in the European Neighbourhood Policy, ${ }^{104}$ the EU's Central Asia Strategy ${ }^{105}$ or

102 Serge Brammertz, 'Arresting Fugitives from International Justice and Other Aspects of State Cooperation: Insights from ICTY Experience', ASP 11, 16 November 2012, https://asp .icc-cpi.int/iccdocs/asp_docs/ASP11/ICC-ASP11-COOP-Keynote_Remarks-Brammertz -ENG.pdf, accessed 29 July 2019. It should be recalled that Croatia's position as a candidate state to join the EU risked delay because of a perceived lack of cooperation with the ICTY. The Council gave its agreement for accession negotiations with Croatia to begin on the basis of a positive assessment of Croatia's cooperation with the ICTY. The full cooperation with the ICTY was posited as a short term priory in the Accession Partnership with Croatia. See Council Decision 2006/145/EC of 20 February 2006 on the principles, priori- ties and conditions contained in the Accession Partnership with Croatia and repealing Decision 2004/648/EC, O.J. L 55/30, 25.2.2006.

103 Commission Staff Working Document: Turkey 2019 Report, Brussels 29.05.2019 (SWD(2019) 220 final) at p. 99. 119 Article 9(1) Council Common Position 2003/444/cfsp https://ec .europa.eu/neighbourhood-enlargement/sitES/NEAR/FILES/20190529-TURKey-report.pdf, accessed 30 July 2019.

104 Applicable to 16 countries in Europe's southern and Eastern neighbourhoods, i.e. Algeria, Armenia, Azerbaijan, Belarus, Egypt, Georgia, Israel, Jordan, Lebanon, Libya,Moldova, Morocco, Palestine, Syria, Tunisia, and Ukraine clauses relating to the ratification and implementation of the Rome Statute are included in all agreements, with the exception of Israel, Morocco, Palestine (already a State Party) and Tunisia.

105 CounciloftheEuropeanUnion, TheEuropeanUnionandCentral Asia:TheNew Partnership in Action', June2009 at pp. 16-17. See also European Commission, Joint communication totheEuropeanParliamentand theCouncil, TheEUandCentralAsia:Newopportunities 
the Cotonou Agreement, ${ }^{106}$ and raised in bilateral negotiations and diplomatic engagements. ${ }^{107}$ Ensuring that such clauses are inserted would give a legitimate basis for political pressure to be exercised when non-cooperation occurs. Only when combining a suitable legal framework with the political support required to encourage States to provide the necessary cooperation through the arrest and surrender of suspects, the collection of evidence, the facilitation of the appearance of victims and witnesses before the Court, would the ICC be able to function properly and fulfil its mandate.

\section{Conclusion}

Having examined the text and application of the Rome Statute provisions, it is clear that as regards cooperation, the Court is constrained by the Statute and by State actions or inactions (of those that choose to become its members, those that owing to Security Councilreferrals find themselves before the Court aswellas third States). In the absence of a directenforcementagency, resorting to States to uphold the cooperation obligations under the Statute can test the Court's effectiveness, particularly when non-cooperation ensues. Even when the Security Council does become involved, its reluctance to weigh in on noncooperation further cripples the already compromised cooperation system.

Therefore, tackling non-cooperation, is a key issue and severely affects the Court's efficiency ${ }^{108}$ The treaty basis of the ICC restricts the available options. An inevitable fault in the institutional design of this Court, which as a treaty regime is grounded to judicial findings of non-cooperation and referrals to the Assembly of States Parties, or the Security Council, in cases of Security Council referrals. ${ }^{109}$

for a Stronger Partnership, Brussels, 15.5.2019 JOIN (2019) 9 final, p. 4 https://eeas.europa.eu/ sites/eeas/files/joint_communication_-_the_eu_and_central_asia_-_new_opportunities _for_a_stronger_partnership.pdf, accessed 30 July 2019.

106 Agreement amending for the second time the Partnership Agreement between the members of the African, Caribbean and Pacific Group of States, of the one part, and the European Community and its Member States, of the other part, signed in Cotonou on 23.06.2000, as first amended in Luxembourg on 25.06.2005, OJ L 287,4.11.2010, atp. 3 .

107 See for exampleEU Annual Report on Human Rights and Democracy in the World 2018, Brussels, 13 May 2019, pp. 96-97, https://eeas.europa.eu/sitES/EEAS/FILES/2018_ANNUAL _report_on_hr_e-version.pdf, accessed 30 July 2019.

108 Annika Jones, 'Non-Cooperation and the Efficiency of the International Criminal Court', in Bekou and Birkett (eds.), supra note 32, pp. 185-209.

109 Article 87(5), (7), Rome Statute. 
Whilst non-cooperation is by no means the only challenge the ICC is facing to date, ${ }^{110}$ it is one that affects the day-to-day functioning of the institution. Considering how to support, strengthen and improve the ICC and the Rome system of justice as a whole, is therefore key to the Court's success. The preceding analysis has showed the strengths and limitations of the (non)cooperation system. Recognising that the Rome Statute framework has its limitations, a new era of pragmatism requires shifting the focus from the Statute to practical ways of ensuring that cooperation is achieved. Re-framing the debate to focus on the possible synergies between the legal framework and the political tools, actions and opportunities at the States' disposal, alongside the judicial findings and current workings of the ASP, is perhaps the only option to tackle non-cooperation and ensure better cooperation in the future.

110 Douglas Guilfoyle, 'This is not fine: The International Criminal Court in Trouble', EJILTALK, www.ejiltalk.org/part-i-this-is-not-fine-the-international-criminal-court- introuble/; http://www.ejiltalk.org/part-ii-this-is-not-fine-the-international-criminal- courtin-trouble/; http://www.ejiltalk.org/part-iii-this-is-not-fine-the-international- criminalcourt-in-trouble/, accessed 30 July 2019. 